\title{
Postgraduate Course SPR 2010: Table of Contents
}

\section{Imaging Challenges and Clinical Perspectives in Pediatric Radiology}

\author{
James S. Donaldson, MD and Cynthia K. Rigsby, MD, Course Directors
}

MRI of the liver- how to do it*

Shreyas S. Vasanawala, MD, PhD

Cross-sectional imaging of pediatric biliary disorders*

Kathleen H. Emery, MD

Imaging of the transplant liver*

Paul S. Babyn, MD

IR of the liver

Philip R. John, MBChB FRCR

MRI of the knee: key points in the pediatric population* Peter J. Strouse, MD

Shoulder pain in the adolescent athlete: a multidisciplinary diagnostic approach from the medical, surgical, and imaging perspectives*

Kelley W. Marshall, MD, David L. Marshall, MD \& Michael T. Busch, MD

Femoral-acetabular impingement: treatment options and results

Michael B. Millis, MD

Hip and groin pain in adolescents*

Tal Laor, MD

Neurocutaneous syndromes: the pediatrician's challenges Robert Listernick, MD

Evaluation of pediatric bone lesions*

Mary R. Wyers, MD

IR challenges in the MSK system*

Neil D. Johnson, MBBS \& John M. Racadio, MD

Academic pediatric radiology in 2010: challenges and opportunities*

George A. Taylor, MD
The pediatric radiologist in private practice*

Susan Palasis, MD

Women in pediatric radiology*

M. Ines Boechat, MD, FACR

The new pediatric radiologist*

Sarah S. Milla, MD \& Ryan W. Arnold, MD

The pediatric radiologist approaching retirement*

Thomas L. Slovis, MD

Sensorineural hearing loss: a medical and surgical perspective

Nancy M. Young, MD

Temporal bone imaging: sensory neural hearing loss and cochlear implants

Francine M. Kim, MD

Cervical spine injuries in pediatrics: are children small adults or not?*

Joseph J. Junewick, MD

Imaging of head and neck neoplasms in children*

Caroline D. Robson, MD

Imaging of tetralogy

Laureen M. Sena, MD

Surgical treatment of tetralogy

Emile A. Bacha, MD

Management of tetralogy from birth through adulthood Tal Geva, MD

*Article included in this issue. 